\title{
Short Communication: Cellular Localization of Haptoglobin mRNA in the Experimentally Infected Bovine Mammary Gland
}

\author{
M. A. Thielen, ${ }^{*}$ M. Mielenz, ${ }^{*}$ S. Hiss, ${ }^{*}$ H. Zerbe, $†$ W. Petzl, $†$ H.-J. Schuberth, $\neq$ \\ H.-M. Seyfert, $§$ and H. Sauerwein ${ }^{\star 1}$ \\ *Institute of Animal Science, Physiology \& Hygiene Group, University of Bonn, 53115 Bonn, Germany \\ †Clinic for Ruminants, University of Munich, 85764 Oberschleissheim, Germany \\ łInstitute for Immunology, University of Veterinary Medicine, 30173 Hannover, Germany \\ §Molecular Biology Research Division, Research Institute for the Biology of Farm Animals, 18196 Dummerstorf, Germany
}

\section{ABSTRACT}

Expression of haptoglobin (Hp) mRNA, one of the major acute phase proteins in cattle, was demonstrated in homogenates of the bovine mammary gland. The aim of this study was to localize Hp mRNA expression within the udder at the cellular level during the first $24 \mathrm{~h}$ of infection with Escherichia coli. For this purpose, 3 quarters of 3 cows were subsequently inoculated with E. coli at 6,12 , and 24 h preslaughter; the fourth quarter received saline at $24 \mathrm{~h}$ preslaughter as a control. After slaughter, tissue samples of each quarter were collected for analyses by in situ hybridization and realtime reverse-transcription PCR. Haptoglobin mRNA expression was allocated to the alveolar epithelium of the mammary gland. Quantification of Hp-positive cells in in situ hybridization of Hp mRNA from tissue homogenates and of $\mathrm{Hp}$ protein in milk confirmed increasing concentrations within $24 \mathrm{~h}$ of infection.

Key words: haptoglobin, mRNA expression, dairy cow, mastitis

In recent years, the concentrations of acute phase proteins measured in blood and, more important, in milk have been discussed as potential diagnostic markers for bovine mastitis (Eckersall et al., 2001; Pedersen et al., 2003; Gronlund et al., 2005). Acute phase proteins are a group of serum proteins predominantly synthesized by the liver. Their concentrations in blood are substantially altered following infection, inflammation, or trauma (Heinrich et al., 1990). Next to serum amyloid $\mathrm{A}$, haptoglobin (Hp) has been described as one of the major acute phase proteins in cattle (Eckersall and Conner, 1988). Elevated concentrations of $\mathrm{Hp}$ in blood as well as in milk were demonstrated during the course of mastitis (Eckersall et al., 2001; Gronlund et al., 2003; Hiss et al., 2004). The discovery of Hp mRNA in homoge-

Received May 31, 2006.

Accepted November 13, 2006.

${ }^{1}$ Corresponding author: sauerwein@uni-bonn.de nates of the mammary gland (Hiss et al., 2004) suggests that $\mathrm{Hp}$ measured in milk might not be completely sourced from circulation, but may at least partly originate from local production within the mammary gland. In addition, Hiss et al. (2004) reported an increase in Hp mRNA transcripts in biopsy samples of the same mammary gland quarter during the initial hours following intramammary application of LPS.

Haptoglobin mRNA expression was shown in bovine circulating leukocytes (Thielen et al., 2005), thus identifying these immune cells as one possible source of $\mathrm{Hp}$ mRNA transcripts found in homogenates of healthy and diseased quarters. Such cells are well known to migrate into the mammary gland of healthy animals at a basal level, but are found in considerably higher numbers during the course of mastitis (Riollet et al., 2000). In support of these immune cells, mammary gland epithelial cells are also known to play an important role in the immediate defense against local infection. In vitro, mammary epithelial cells produce not only proinflammatory cytokines such as tumor necrosis factor- $\alpha$ and interleukin-8 (CXCL-8), but also the acute phase proteins serum amyloid $\mathrm{A}$ and lactoferrin after stimulation with pathogens or endotoxins (Wellnitz and Kerr, 2004). However, Hp synthesis by the cells of the mammary gland itself has not been demonstrated so far. The aim of this study was to localize Hp mRNA at the cellular level in the bovine mammary gland at $24 \mathrm{~h}$ following intramammary Escherichia coli infection.

The trial was carried out with 3 German Holstein cows in the middle of their first or second lactation under the approval of the ethics committee of the regional government in Hannover, Germany (No. 509.642502-03/678). Quarter milk of these animals had been tested weekly 3 times pretrial and on the day of the trial to ensure that it was free of mastitis pathogens and had less than 100,000 somatic cells $/ \mathrm{mL}$ in the samples from each quarter. The cows were inoculated intramammarily with $500 \mathrm{cfu}$ of $E$. coli, which was isolated and cultured from natural cases of clinical mastitis. The pathogens were suspended in $2 \mathrm{~mL}$ of saline and 
administered through the teat canal intracisternally into the right front, right hind, and left hind quarters at 0 (T0), 12 (T12), and $18 \mathrm{~h}$ (T18), respectively, after the start of the trial. The left front quarter received 2 $\mathrm{mL}$ of pathogen-free saline at T0. Cows were milked at T0 and T12 just prior to the inoculations and at $24 \mathrm{~h}$ after the start of the trial (T24). Milk samples from all 4 quarters were taken at T24. Finally, cows were killed at T24 with a penetrating captive bolt gun followed by exsanguination. Samples of quarter mammary gland samples were snap-frozen in liquid nitrogen and stored at $-80^{\circ} \mathrm{C}$ for ISH and real-time reverse-transcription PCR. For in situ hybridization (ISH) analyses, ribonucleotide bovine $\mathrm{Hp}$ antisense and sense probes (302 bp) were synthesized by in vitro transcription from a DNA template that resulted from PCR with bovine Hp primers [5'-CCAAAGGCAGCTTTCCTTGG-3' (forward), 5'GGAAGGTAGGCAGATGGGCAT-3' (reverse); Lavery et al., 2004], extended by a spacer plus T7 promotor sequence. This allowed us to transcribe the probes in reverse and simultaneously to label them with digoxigenin (digoxigenin RNA labeling kit; Roche, Mannheim, Germany). Cryosections (12 $\mu \mathrm{m})$ were fixed in $4 \%$ paraformaldehyde for $15 \mathrm{~min}$, rinsed in PBS, and then treated by an ascending and then a descending alcohol series of ethanol. The sections were incubated in $0.3 \%$ $\mathrm{H}_{2} \mathrm{O}_{2}$ in $\mathrm{PBS}$ for 15 min to inactivate endogenous peroxidase, washed twice in PBS, and further pretreated with $0.25 \%$ acetic anhydride in $0.1 \mathrm{M}$ triethanolamine $(\mathrm{pH}$ 8.0) for $10 \mathrm{~min}$. After equilibration in $2 \times$ sodium chloride-sodium citrate (SSC), sections were overlaid with $50 \mu \mathrm{L}$ of hybridization buffer (10\% dextran sulfate, $50 \%$ deionized formamide, $150 \mathrm{mM} \mathrm{NaCl}, 2 \times \mathrm{SSC}, 0.2 \mathrm{mg} /$ $\mathrm{mL}$ of yeast tRNA, $1 \mathrm{mg} / \mathrm{mL}$ of fish sperm DNA, $1 \times$ Denhardt's solution) containing $3 \mathrm{ng}$ of probe denatured at $80^{\circ} \mathrm{C}$ for $5 \mathrm{~min}$, and hybridized at $52^{\circ} \mathrm{C}$ in a humid chamber overnight. Excess probe was removed by washing twice in $2 \times \mathrm{SSC}$ at $45^{\circ} \mathrm{C}$, twice in $50 \% 2 \times \mathrm{SSC}-50 \%$ deionized formamide at $45^{\circ} \mathrm{C}$, and twice in $0.2 \times \mathrm{SSC}$. In addition, sections were subjected to an RNase digest [ $5 \mu \mathrm{g} / \mathrm{mL}$ of RNase A, $50 \mathrm{U} / \mathrm{mL}$ of RNase T1 (Fermentas, St. Leon-Rot, Germany) in $\left.2 \times \mathrm{SSC}, 37^{\circ} \mathrm{C}, 30 \mathrm{~min}\right]$ and 3 washes in PBS. Next, the hybridization signal was visualized by applying the tyramide signal amplification system [TSA Plus DNP (AP) System; PerkinElmer LAS, Rodgau-Jügesheim, Germany] according to the manufacturer's protocol but prolonging both antibody incubation times to $1 \mathrm{~h}$. The final reaction with the substrates 5-bromo-4-chloro-indolyl phosphate and nitroblue tetrazolium was stopped by Tris-EDTA buffer, and sections were mounted with Kaiser's glycerol gelatine (Merck Eurolab GmbH, Darmstadt, Germany). Mammary gland tissue sections hybridized with sense probe or subjected to the ISH protocol without adding any probe were used as negative controls. Staining per section was scored using a reference grid $(1 \times 1 \mathrm{~cm}, 10$ $\times 10$ squares) under the microscope; stained cells of 24 squares, randomly picked but analogously fixed for all sections, were counted at a total magnification of 260 .

Haptoglobin mRNA concentrations were evaluated by quantitative real-time PCR in a MX3000P real-time PCR system (Stratagene Europe, Amsterdam, the Netherlands) as follows. Total RNA was extracted from mammary gland tissue using the NucleoSpin RNA II kit (Macherey-Nagel, Düren, Germany) according to the manufacturer's instructions, which included DNase I digestion. A 1.8- $\mu$ g quantity of total RNA were reversetranscribed using hexamer primers in $20 \mu \mathrm{L}$, and controls were performed as described by Thielen et al. (2005). Polymerase chain reaction was carried out in a total volume of $20 \mu \mathrm{L}$ using SYBR Green JumpStart Taq ReadyMIX (Sigma, Taufkirchen, Germany). The Hp primers, used at a concentration of $100 \mathrm{n} M$, are described in Hiss et al. (2004; amplicon size, $174 \mathrm{bp}$ ); the 18S rRNA primers [5'-GAGAAACGGCTACCACATCC$3^{\prime}$ (forward) and 5'-CACCAGACTTGCCCTCCA-3' (reverse)] were applied at a concentration of $50 \mathrm{n} M$ (amplicon size, $170 \mathrm{bp}$ ). The amplicons were checked by gel electrophoresis, and the product for 18S rRNA was verified by direct sequencing. Quantification was conducted against a standard dilution series established with PCR products. The results for Hp were normalized against the results obtained by amplification of $18 \mathrm{~S}$ rRNA. For PCR, $2 \mu \mathrm{L}$ of the reverse-transcription reaction mix, diluted 1:4, was used for the analysis of $\mathrm{Hp}$ mRNA, and that diluted 1:400 was used for the analysis of $18 \mathrm{~S}$ rRNA. Both genes were analyzed with the following cycling conditions: $95^{\circ} \mathrm{C}, 60 \mathrm{~s} ; 58^{\circ} \mathrm{C}, 30 \mathrm{~s} ; 72^{\circ} \mathrm{C}, 30 \mathrm{~s}$ after an initial denaturation step of $10 \mathrm{~min}$ at $95^{\circ} \mathrm{C}$.

Haptoglobin protein in skimmed milk was measured with an ELISA (Hiss et al., 2004) with minor modifications such that a standard serum was applied for coating and as the calibration curve instead of $\mathrm{Hp}$ purified from bovine serum. The serum used herein had been calibrated against a standard obtained from European Union Concerted Action on the standardization of animal acute phase proteins (QLKS-T-1999-0153; Skinner, 2001). The scoring of the ISH staining, milk protein data, and quantitative Hp mRNA data of the mammary glands was analyzed by a nonparametric paired-samples test (Friedman's test) in SPSS 12.0 (SPSS Science Software, Erkrath, Germany). A $P$-value of $<0.05$ was considered significant. The infection model applied clearly induced mastitis, as reflected by the increase in the mean SCC of $7.5 \times 10^{3}$ cells $/ \mathrm{mL}$ (range of $2 \times 10^{3}$ cell $/ \mathrm{mL}$ to $81 \times 10^{3}$ cell $\mathrm{s} / \mathrm{mL}$ ) preinoculation to at least $3.8 \times 10^{6}$ cells $/ \mathrm{mL}$ at $24 \mathrm{~h}$ postinoculation. Escherichia 

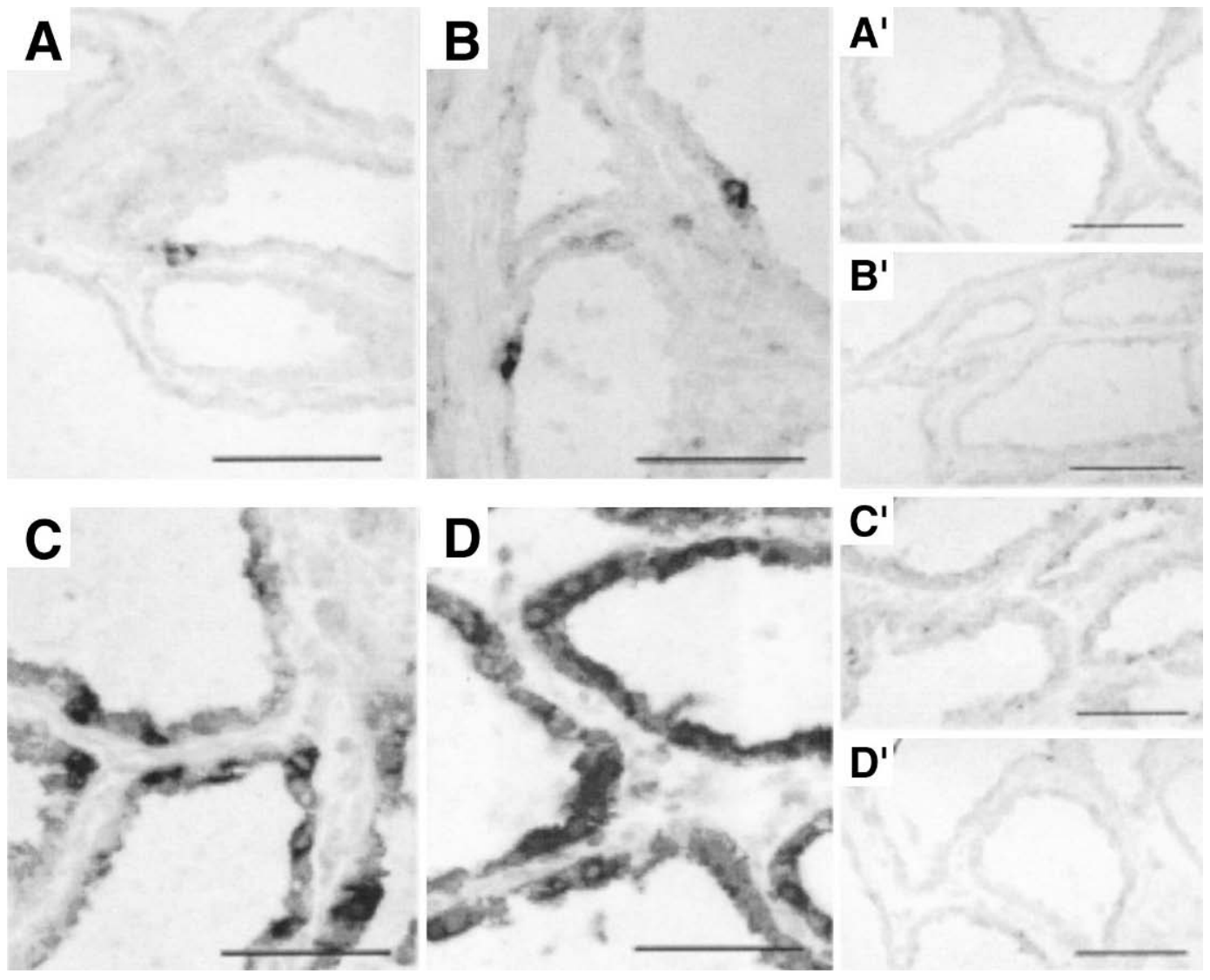

Figure 1. Localization of haptoglobin (Hp) mRNA expression by in situ hybridization (ISH; dark staining) in the alveolar epithelium of the bovine mammary gland after cows had been subjected to IMI with Escherichia coli. Three quarters of each cow were inoculated with the pathogen at $6(\mathrm{~B}), 12(\mathrm{C})$, and $24 \mathrm{~h}(\mathrm{D})$ preslaughter; the fourth quarter received saline as a control at $24 \mathrm{~h}$ preslaughter (A). Tissues were hybridized with antisense probe (A to $\mathrm{D})$ and corresponding near-serial sections with sense probe $\left(\mathrm{A}^{\prime}\right.$ to $\left.\mathrm{D}^{\prime}\right)$. Bars represent $50 \mu \mathrm{m}$.

coli was reisolated from the right front, right hind, and left hind quarters after $24 \mathrm{~h}$.

Haptoglobin mRNA was localized at the cellular level in the alveolar epithelial cells of bovine mammary glands by ISH. Figure 1 exemplifies the results from one cow. To our knowledge, this is the first report on the cellular localization of $\mathrm{Hp}$ mRNA expression in the bovine mammary epithelium. It furthers the recent finding that the mammary gland is a possible site of Hp mRNA expression in cattle (Hiss et al., 2004). In addition, it is recognized that the bovine mammary gland epithelium expresses other acute phase proteins such as lactoferrin, mammary-associated serum amyloid A 3, and mammary serum amyloid A 3 homologue (Molenaar et al., 1996; McDonald et al., 2001; Molenaar et al., 2002). Examining the results in more detail, we found that the number of cells with specific ISH staining signals per mammary alveolus was low in the control quarter (Figure 1A) and increased with increasing incubation time in the other quarters (Figure 1B to $1 D$ ), which was numerically underlined by the scoring re- sults of the ISH staining (Table 1). The distribution pattern of the stained cells ranged from single cells being scattered across the section of the control quarter to all epithelium cells being stained uniformly in the quarter infected for $24 \mathrm{~h}$. No specific hybridization signals were present in any section incubated with sense probe (Figure $1 \mathrm{~A}^{\prime}$ to $1 \mathrm{D}^{\prime}$ ) or without any probe (data not shown) as ISH controls.

Quantification of intramammary Hp mRNA expression by real-time PCR revealed that, despite strong individual variance, an increase in the mean Hp mRNA concentration was observed over the time of experimental infection, compared with the control value (Table 1). In milk, the Hp protein concentrations in samples from all 4 quarters differed significantly, and values totaled 169 -fold higher at $24 \mathrm{~h}$ after infection when compared with the control quarter (Table 1). This increase in Hp mRNA abundance in mammary quarters, as well as the Hp protein concentration in milk observed as the $E$. coli infections progressed, is analogous to the findings by Hiss et al. (2004) from an E. coli-lipopolysac- 
Table 1. Results (mean \pm SEM) of the scoring of cells in sections of the mammary gland with specific in situ hybridization (ISH) staining for haptoglobin $(\mathrm{Hp})$ mRNA, quantification of Hp mRNA expression, and analysis of the Hp protein concentration in milk, depending on the duration of quarter infection with Escherichia coli

\begin{tabular}{|c|c|c|c|c|c|}
\hline \multirow[b]{2}{*}{ Item } & \multicolumn{4}{|c|}{ Duration of infection per quarter, $\mathrm{h}$} & \multirow[b]{2}{*}{$\mathrm{S}^{1}$} \\
\hline & 0 & 6 & 12 & 24 & \\
\hline $\begin{array}{l}\text { Abundance of cells with Hp mRNA in } \\
\text { ISH sections, stained cells/square }\end{array}$ & $0.3 \pm 0.2$ & $0.5 \pm 0.3$ & $1.7 \pm 1.5$ & $17.1 \pm 5.7$ & * \\
\hline Relative gene expression, $\mathrm{Hp} / 18 \mathrm{~S}$ rRNA & $\begin{array}{r}3.2 \times 10^{-4} \\
\pm 2.2 \times 10^{-4}\end{array}$ & $\begin{array}{r}7.3 \times 10^{-4} \\
\pm 3.24 \times 10^{-4}\end{array}$ & $\begin{array}{r}3.8 \times 10^{-3} \\
\pm 3.4 \times 10^{-3}\end{array}$ & $\begin{array}{r}5.6 \times 10^{-2} \\
\pm 3.4 \times 10^{-2}\end{array}$ & $\begin{array}{l}* \\
*\end{array}$ \\
\hline $\mathrm{Hp}$ in milk, $\mu \mathrm{g} / \mathrm{mL}$ & $2.7 \pm 0.7$ & $3.4 \pm 0.8$ & $56.5 \pm 30.9$ & $456.3 \pm 101.1$ & * \\
\hline
\end{tabular}

${ }^{1}$ Significance: ${ }^{*} P<0.05$.

charide intramammary challenge. In that study, the first elevations of both Hp mRNA transcripts and the milk $\mathrm{Hp}$ concentration were detected already at $3 \mathrm{~h}$ postchallenge.

Haptoglobin mRNA in the present study was not localized in leukocytes. This lack of an ISH signal is in contrast to an earlier study identifying Hp mRNA in extracted blood leukocytes (Thielen et al., 2005) and might be explained by insufficient sensitivity of the ISH method applied; Lavery et al. (2004) failed to detect Hp mRNA in bovine oviduct by ISH, yet a positive signal was revealed by Northern blotting.

The physiological benefits of local Hp expression in the mammary gland during infection might be manifold. One characteristic of $\mathrm{Hp}$ is its down-regulation of the host immune response by suppressing production of proinflammatory cytokines in monocytes (Arredouani et al., 2005) as well as by inhibiting the respiratory burst activity in neutrophils (Oh et al., 1990). The local synthesis of $\mathrm{Hp}$ in the mammary gland might allow this down-regulation to occur on-site immediately and might be advantageous over the delayed supply resulting from systemic up-regulation of $\mathrm{Hp}$ production in the liver. Another well-known property of $\mathrm{Hp}$ is that it binds hemoglobin. Consequently, this retards the iron-requiring process of bacterial replication, as demonstrated during $E$. coli infection in mice in vivo (Eaton et al., 1982), and inhibits oxidative damage caused by free hemoglobin (Miller et al., 1997). In conclusion, the mammary epithelium cells represent an additional extrahepatic source of $\mathrm{Hp}$ and function as a possible source of $\mathrm{Hp}$ found in milk.

\section{ACKNOWLEDGMENTS}

We thank the North Rhine-Westphalian Ministry of Environment, Conservation, Agriculture and Consumers Protection (MUNLV) for supporting this study within the Inter-Departmental Center of Sustainable Agriculture (USL).

\section{REFERENCES}

Arredouani, M. S., A. Kasran, J. A. Vanoirbeek, F. G. Berger, H. Baumann, and J. L. Ceuppens. 2005. Haptoglobin dampens endotoxin-induced inflammatory effects both in vitro and in vivo. Immunology 114:263-271.

Eaton, J. W., P. Brandt, J. R. Mahoney, and J. T. Lee. 1982. Haptoglobin: A natural bacteriostat. Science 215:691-693.

Eckersall, P. D., and J. G. Conner. 1988. Bovine and canine acute phase proteins. Vet. Res. Commun. 12:169-178.

Eckersall, P. D., F. J. Young, C. McComb, C. J. Hogarth, S. Safi, A. Weber, T. McDonald, A. M. Nolan, and J. L. Fitzpatrick. 2001. Acute phase proteins in serum and milk from dairy cows with clinical mastitis. Vet. Rec. 148:35-41.

Gronlund, U., C. Hallen Sandgren, and K. Persson Waller. 2005. Haptoglobin and serum amyloid A in milk from dairy cows with chronic sub-clinical mastitis. Vet. Res. 36:191-198.

Gronlund, U., C. Hulten, P. D. Eckersall, C. Hogarth, and K. Persson Waller. 2003. Haptoglobin and serum amyloid A in milk and serum during acute and chronic experimentally induced Staphylococcus aureus mastitis. J. Dairy Res. 70:379-386.

Heinrich, P. C., J. V. Castell, and T. Andus. 1990. Interleukin-6 and the acute phase response. Biochem. J. 265:621-636.

Hiss, S., M. Mielenz, R. M. Bruckmaier, and H. Sauerwein. 2004. Haptoglobin concentrations in blood and milk after endotoxin challenge and quantification of mammary $\mathrm{Hp}$ mRNA expression. J. Dairy Sci. 87:3778-3784.

Lavery, K., C. Gabler, J. Day, and G. Killian. 2004. Expression of haptoglobin mRNA in the liver and oviduct during the oestrous cycle of cows (Bos taurus). Anim. Reprod. Sci. 84:13-26.

McDonald, T. L., M. A. Larson, D. R. Mack, and A. Weber. 2001. Elevated extrahepatic expression and secretion of mammary-associated serum amyloid A 3 (M-SAA3) into colostrum. Vet. Immunol. Immunopathol. 83:203-211.

Miller, Y. I., S. M. Altamentova, and N. Shaklai. 1997. Oxidation of low-density lipoprotein by hemoglobin stems from a hemeinitiated globin radical: Antioxidant role of haptoglobin. Biochemistry 36:12189-12198.

Molenaar, A. J., Y. M. Kuys, S. R. Davis, R. J. Wilkins, P. E. Mead, and J. W. Tweedie. 1996. Elevation of lactoferrin gene expression in developing, ductal, resting, and regressing parenchymal epithelium of the ruminant mammary gland. J. Dairy Sci. 79:1198-1208.

Molenaar, A. J., G. Rajan, M. Pearson, M. Miles, R. Petrova, S. Davis, and K. Stelwagen. 2002. A serum amyloid protein homologue is expressed by the mammary gland in a similar pattern to lactoferrin. Page 42 in Food Safety and Acute Phase Proteins. G. H. M. Counotte, M. J. M. Toussaint, A. van Ederen, and E. Gruys, ed. Department of Pathology, Faculty of Veterinary Medicine, Utrecht.

Oh, S. K., N. Pavlotsky, and A. I. Tauber. 1990. Specific binding of haptoglobin to human neutrophils and its functional consequences. J. Leukoc. Biol. 47:142-148. 
Pedersen, L. H., B. Aalbaek, C. M. Rontved, K. L. Ingvartsen, N. S. Sorensen, P. M. Heegaard, and H. E. Jensen. 2003. Early pathogenesis and inflammatory response in experimental bovine mastitis due to Streptococcus uberis. J. Comp. Pathol. 128:156164.

Riollet, C., P. Rainard, and B. Poutrel. 2000. Differential induction of complement fragment C5a and inflammatory cytokines during intramammary infections with Escherichia coli and Staphylococcus aureus. Clin. Diagn. Lab. Immunol. 7:161-167.
Skinner, J. G. 2001. International standardization of acute phase proteins. Vet. Clin. Pathol. 30:2-7.

Thielen, M. A., M. Mielenz, S. Hiss, and H. Sauerwein. 2005. Qualitative detection of haptoglobin mRNA in bovine and human blood leukocytes and bovine milk somatic cells. Vet. Med. Czech. 50:515-520.

Wellnitz, O., and D. E. Kerr. 2004. Cryopreserved bovine mammary cells to model epithelial response to infection. Vet. Immunol. Immunopathol. 101:191-202. 